Article

\title{
Interactions among Environmental Training, Environmental Strategic Planning and Personnel Controls in Radical Environmental Innovation
}

\author{
Rogério João Lunkes ${ }^{1, *} \mathbb{C}^{\text {, Fabricia Silva da Rosa }}{ }^{1}{ }^{\mathbb{C}}$, Januário José Monteiro ${ }^{2}$ and \\ Daiane Antonini Bortoluzzi ${ }^{3}$ (D) \\ 1 Department of Accounting, Federal University of Santa Catarina, Florianópolis 88040-900, Brazil; \\ fabricia.rosa@ufsc.br \\ 2 Graduate Program in Accounting, Federal University of Santa Catarina, Florianópolis 88040-900, Brazil; \\ januario.monteiro@posgrad.ufsc.br \\ 3 Department of Administration, Federal University of Santa Catarina, Florianópolis 88040-900, Brazil; \\ daiane.antonini@ufsc.br \\ * Correspondence: rogerio.lunkes@ufsc.br
}

Received: 21 August 2020; Accepted: 13 October 2020; Published: 21 October 2020

\begin{abstract}
The purpose of this study was to analyze the effect of environmental training on the relationship between environmental strategic planning and personnel controls in radical environmental innovation. To collect the data, we designed a questionnaire for companies in the Brazil Stock Exchange (B3-Brazil, Bolsa, and Balcão). Data from 150 companies were analyzed using structural equation modeling and fuzzy-set qualitative comparative analysis (FsQCA). The results show that environmental strategic planning and personnel controls affect radical environmental innovation. The findings also show that environmental training impacts the relationship between environmental strategic planning and personnel controls in radical environmental innovation. The asymmetric approach reinforces this evidence and suggests that environmental training is a central element that leads to high radical environmental innovation. The study contributes to the literature by showing that environmental training assists in the management of radical environmental innovation by aligning individual and organizational objectives.
\end{abstract}

Keywords: radical environmental innovation; environmental strategic planning; personnel controls; environmental training

\section{Introduction}

Environmental pollution causes destruction to the natural environment and damage to the economy. Thus, improving performance and preserving the environment have become important concerns for firms [1]. Radical environmental innovation (REI) makes it possible to correct more serious environmental problems while simultaneously improving the productivity of companies and is an efficient strategy for achieving good environmental and economic performance [2]. REI serves to improve environmental performance and requires heterogeneous knowledge and high levels of technology and organizational resources [1]. Moreover, REI is designed to improve products/processes/ services by reducing the consumption of natural resources, the emissions of greenhouse gases and/or environmental impacts [3].

Previous studies have shown that REI requires disruptive forces and advanced methods [1]. The literature reveals that the strategy favors decision making about environmental innovation [4], while management controls enable the effectiveness of innovative environmental objectives $[5,6]$. There is evidence of a positive relationship between strategic planning and personnel controls with 
environmental innovation [5,7]. Thus, companies with an alignment of management commitment, strategic planning and proactive management actions can improve their environmental performance [8]. In addition, employee training with a specific focus on the environment makes it possible for employees to understand, monitor and coordinate the achievement of pre-established environmental goals $[3,9]$. It is known that radically innovative products/processes/services presuppose profound cultural changes; consequently, personnel controls and environmental training are important tools that allow for the alignment of individual and organizational values [5,7].

The literature shows that strategic planning and personnel controls lead companies to develop environmental innovation. In addition to environmental training, it is possible to align individual and institutional objectives. However, little is known about the training effects on the relationship between environmental strategic planning and personnel controls in REI. Therefore, there exists an opportunity to see how the joint integration of these elements enables the execution of REI within companies. We understand that this relationship enhances REI, as this type of innovation requires highly trained personnel and a high level of organizational resources $[3,10,11]$. This presupposes the incorporation of comprehensive information on environmental innovation in strategy [3] and personnel controls [8] aimed at providing alignment between the individual and institutional objectives of REI. To explore the existing gap in REI, the present study aims to analyze the effect of environmental training on the relationship between environmental strategic planning and personnel controls in radical environmental innovation. For this study, data from 150 companies listed in the Brazil Stock Exchange (B3) were analyzed using structural equation modeling and fuzzy-set qualitative comparative analysis (FsQCA).

Our study contributes to the existing literature by analyzing the interactions among strategic planning, personnel controls and environmental training in REI. This study generates new insights into the factors that influence the performance of REI in large companies, showing that there are multiple factors, such as environmental strategic planning, personnel controls and environmental training, that contribute to improving REI. Thus, the study advances the extant knowledge by analyzing the interaction between strategic planning and personnel control, with a focus on environmental issues. Through the FsQCA approach, we show that environmental training is a central element for organizations that seek constant innovation in ecologically sustainable products and services. In practice, the study contributes to the work of managers by showing that the use of strategic environmental planning and personnel controls is associated with REI for products and work practices. This study demonstrates the relevance of environmental training for aligning individual and institutional objectives. In addition to revealing that REI requires greater resource effort and greater knowledge, the results obtained apply to the long term.

The study is structured as follows. Section 2 discusses the background and hypothesis formulation. Section 3 outlines the materials and methods employed in the study. Sections 4 and 5 present the analysis and discussion, respectively. Section 6 presents the conclusions.

\section{Background and Hypothesis Development}

\subsection{Environmental Strategic Planning, Personnel Controls and Radical Environmental Innovation}

Environmental innovation (AI) refers to improvements in the products, processes and services that lead companies to achieve increased environmental performance-for example, material and energy savings, pollution control and prevention, waste management, recycling and ecological design [3]. AI can be incremental, radical and ambidextrous. Incremental innovation is characterized by small improvements that use existing technologies and target existing markets [12]. Radical innovation refers to fundamental or revolutionary changes in existing products, services or processes that use advanced environmental technology [13]. Ambidextrous innovation, conversely, occurs when incremental and radical innovation coexist in the company and demands broader organizational resources, operational and strategic controls, and holistic and dynamic management capacity; these results apply in both the short term and the long term. Therefore, dynamic tension must be considered by managers so that the company can achieve its operational and strategic objectives for environmental innovation $[14,15]$. 
We argue that studies on REI should be expanded, as this type of environmental innovation leads to greater organizational changes [16]. This innovation involves the use of a high level of resources $[3,10,11]$, the development of innovative technologies or the reconfiguration of services and production systems [12], as well as heterogeneous knowledge [1].

Studies show that the alignment between strategy [3], controls and knowledge [8] assists companies in making profound organizational changes that make it possible to achieve REI and superior performance. This is because the proactive environmental strategies (e.g., strategic planning) considered in the REI process improve the environmental and financial results [8] and generate added value for products and markets [4]. For example, feedback and measurement systems can protect innovation by attracting attention, stimulating actions toward specific projects and generating responsibility in the use of the resources invested in projects [17]. Therefore, it is understood that environmental strategic planning is a factor that influences corporate environmental responsiveness because it is a proactive strategy with dynamic capability and is dependent on specific and identifiable processes [8]. Companies that have successfully aligned their management commitment, strategic planning and proactivity report better environmental and financial results [8]. In view of this evidence, the following research hypothesis emerges:

\section{Hypothesis 1 (H1): Environmental strategic planning positively affects radical environmental innovation.}

In addition to the implementation of environmental strategic planning, the adoption of formal compliance policies and procedures is necessary to ensure appropriate employee behaviors [5]. To manage this system, companies can use personnel controls with appropriate employee selection, training and development approaches aimed at directing employee behaviors [5,18]. In this case, personnel controls can assist in the selection of employees who have adapted to the REI process. Personnel controls can be aimed at supporting REI by hiring committed employees with specific knowledge [10,11].

It is expected that the personnel controls related to the selection, training and development of employees may be strongly associated with REI. This is because the intensification of these controls can produce congruence and synergy for companies' radical innovations. Since REI requires highly qualified personnel to develop innovative technologies or reconfigure production service systems [12], we hope that companies that emphasize the use of personnel controls will have a greater number of adapted employees to implement these innovations. Studies show that personnel controls that include processes to involve, influence, motivate and inspire employees can positively affect commitment [19] and consequently innovation [20]. With this evidence in mind, we propose that the adoption of personnel controls positively affects REI. Thus, the second research hypothesis emerges:

Hypothesis 2 (H2): Personnel controls positively affect radical environmental innovation.

\subsection{Environmental Training}

REI demands specific knowledge; therefore, environmental training creates new knowledge and skills that stimulate the absorptive capacity for innovation [21]. Thus, environmental training becomes a critical tool that allows employees to adopt new perspectives, skills and attitudes [3]. As a consequence, it allows them to understand, monitor and coordinate the achievement of pre-established environmental goals [9] and environmental strategies [3]. The literature also reveals that environmental training allows for the alignment of personnel controls (recruitment, selection and hiring) with REI. This alignment is because the training and development of employees can be an important factor in achieving congruence between individual and organizational values [5]. These values can be decisive for personnel controls and companies' strategies that promote radical environmental innovation. As a result, environmental training is related to personnel controls, strategic environmental planning 
and REI, as it allows for the alignment of employee and company values and strategies to promote innovation. Based on this line of reasoning, the following research hypotheses are indicated:

Hypothesis 3a (H3a): Environmental training positively affects the relationship between strategic planning and radical environmental innovation;

Hypothesis $3 \mathbf{b}$ (H3b): Environmental training positively affects the relationship between personnel controls and radical environmental innovation.

\subsection{Radical Environmental Innovation and Economic Performance}

The relationship between REIs can be positive, negative or uncertain [22-26]; specifically, it can have negative effects depending on the context [27-29], which can be explained by the fact that REI is a highly expensive process with high degrees of uncertainty [30,31] and risk [31]. Due to its high cost and risk [30,31], it is considered that REI's return is generally long term [32,33]. We argue in this study that the effect of REI on short-term economic performance is negative, and the fourth research hypothesis emerges:

Hypothesis 4 (H4): Radical environmental innovation negatively affects economic performance.

Our underlying conceptual research model and its associated hypotheses are summarized in Figure 1.

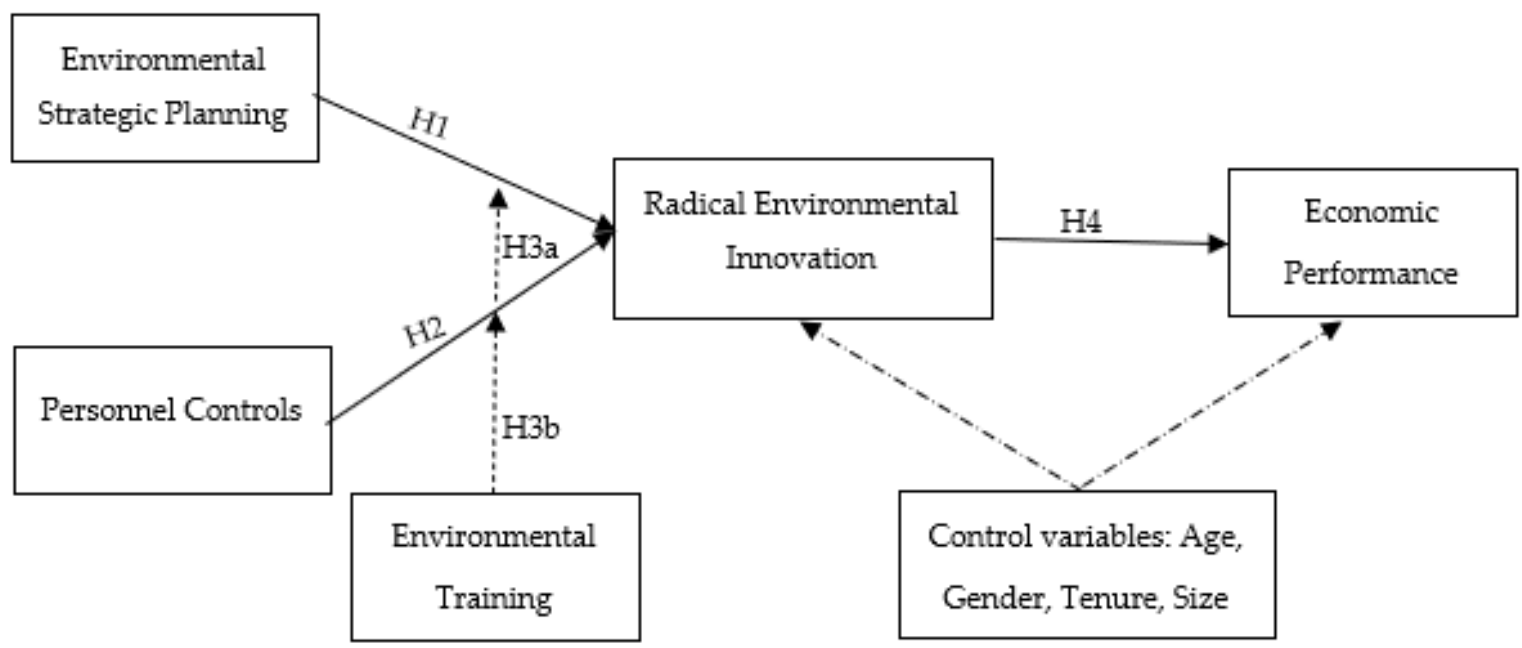

Figure 1. Theoretical research model.

\section{Materials and Methods}

\subsection{Sample and Data Collection}

The research population consists of 423 publicly traded companies listed in the stock exchange (B3-Brazil, Bolsa, and Balcão). As the research aims to understand how large companies adopt environmental strategic planning and personnel controls to achieve REI, it was necessary to interview senior managers who were directly involved with these issues (e.g., CEOs, CFOs, controllers or other Top management team-TMT). The selection of large companies leads to the greater probability that duly formalized management systems are present [34].

A questionnaire based on the literature was designed for the data collection. The questions related to environmental strategic planning were based on the study by [8] and further tested by [4]. The personnel control items were captured from the study of [5] and from the environmental training in the research 
of [9] and [3]. The REI items were based on studies by [14,15,35,36] and economic performance studies by $[4,37]$. Additional questions were asked to capture demographic variables, gender, age, tenure and size [9]. Before the data collection, pretests were conducted with four academics with experience in the field. The comments received were related to the verification of the understanding of the items, extent and response time.

The questionnaire data collection was carried out by a company specialized in marketing and academic research from April to May 2020. For the data collection, the contractor followed the recommendations of [38]. First, an initial contact was made with the senior executives of the companies via telephone. In this stage, the manager's participation in the research was requested. Those who agreed to participate received a letter of introduction and a link to access the questionnaire. A second request was made five days later, and a third request was made 10 days after the first contact. Overall, 150 valid questionnaires were obtained, representing a response rate of approximately $35.5 \%$. This response rate is representative and comparable to the response rates indicated in the literature e.g., $[9,15,24]$. The data regarding economic performance were collected from the Economatica database (https://economatica.com). Through this database, it was possible to obtain consolidated economic and financial data from companies registered with B3. The companies' economic data were collected from the financial reports for the period from April to June 2020.

\subsection{Measurement of Key Variables}

\subsubsection{Environmental Strategic Planning}

This construct evaluated how much managers agreed with statements that captured the use of planning for environmental strategy. It was composed of three questions and was based on the work of $[4,8]$ and aimed at identifying whether (i) environmental issues were explicitly considered within the company's strategic planning process, (ii) environmental issues were addressed in the company's mission statement or the statement of business principles and (iii) the top management team makes proactive forward-thinking decisions when environmental issues are considered within the strategic planning process. A seven-point Likert scale was applied ( $1=$ strongly disagree to $7=$ strongly agree).

\subsubsection{Personnel Controls}

This construct captured managers' perceptions of the use of personnel controls. It was composed of five questions and was based on the study by [5] that evaluated the extent of use of personnel controls, considering (i) the selection criteria according to the values and norms of the organization, (ii) efforts to better establish a more suitable recruitment process, (iii) emphasis on hiring the most suitable candidates, (iv) training and employee development activities, and (v) opportunities to expand their employees' range of skills. A seven-point Likert scale was applied ( $1=$ strongly disagree to $7=$ strongly agree).

\subsubsection{Environmental Training}

This construct aimed to assess managers' perceptions of environmental training. It was composed of five questions and was based on the study by [9] that aimed to assess the degree of accomplishment of (i) the environmental training of employees in a continuous and systematic way, (ii) the periodic training of employees (persons not linked to the company but who can contribute in some way), (iii) continuous environmental training with suppliers, (iv) environmental training with the local community in a systematic and continuous manner (with events and instructional materials such as booklets and web conferences), and (v) periodic activities to raise awareness of environmental issues. A seven-point Likert scale was applied ( $1=$ strongly disagree to $7=$ strongly agree).

\subsubsection{Radical Environmental Innovation}

This construct aimed to assess the perception of managers in relation to the capacity of companies to radically innovate on environmental issues. It was composed of four questions and was adapted to 
the study by $[15,39]$ and identified whether the organization (i) systematically innovates work practices to generate environmental benefits, (ii) has launched new products/services during the last three years to generate environmental benefits, (iii) uses services from companies specialized in environmental innovation (e.g., consultancy companies), and (iv) has a partnership with suppliers, customers or competitors to develop environmental innovation. A seven-point Likert scale was applied ( $1=$ strongly disagree to $7=$ strongly agree).

\subsubsection{Economic Performance}

This construct is composed of the consolidated financial data from April to June of 2020 of the companies investigated. Based on the literature, the Return on assets (ROA), Return on equity (ROE) and Return on investment (ROI) were considered proxies for economic performance, e.g., [4,37].

\subsubsection{Control Variables}

It is expected that the characteristics of managers influence their organizations' ability to innovate as well as their organizations' economic performance. Based on the literature, we considered gender, age, tenure and size as control variables $[9,15]$.

\subsection{Data Analysis}

For an analysis of the data, we used structural equation modeling (SEM) based on partial least squares. The SEM approach follows the steps of validating the measurement model using the PLS algorithm technique and applying the structural model using bootstrapping and blindfolding techniques [40]. This choice of technique is justified because it is widely used in studies in management $[15,41]$ and environmental accounting [4]. In addition, the technique is adequate to meet the research objectives and evaluate the study's hypotheses. This approach does not require normal data, so it is a nonparametric technique [40].

To understand the behavior of radical environmental innovation antecedents, we carried out a complementary analysis based on an asymmetric approach [42]. In this step, the FsQCA technique (fuzzy-set qualitative comparative analysis) was used, as it allows us to identify possible solutions that lead to high-level outcomes [43]. For the execution of the FsQCA, it is first necessary to calibrate the variables [43]. For the calibration process, the 10th percentile was considered non-membership, the 50th percentile was the crossover point, and the 90th percentile was full membership, as recommended by [44]. The second stage involved the identification of necessary and sufficient conditions through the truth table [43]. This combined approach of PLS and FsQCA has been recurrent in the literature [42,45] and helps us better understand the findings [42].

\section{Results}

\subsection{Measurement Model}

In the measurement model, the reliability and validity of the constructs were evaluated [40]. The constructs show composite reliability (CR) greater than 0.70 , so they are considered reliable. For validity, the constructs present a stroke greater than 0.50 , thus meeting the convergent validity criterion. Items that present factorial loads below the 0.60 threshold are excluded (ESP1, PC1 and PC2) because they impair validity and reliability [40]. In this way, the criteria of the measurement stage are met. The results of the measurement model are described in Table 1.

In addition to constructs that meet the reliability and convergent validity criteria, as seen in Table 1 , it is also necessary to consider discriminant validity. We evaluated this using the criteria of Fornell and Larcker and the heterotrait-monotrait (HTMT) ratio, as recommended by [40]. Table 2 presents the results of the discriminant validity evaluation. 
Table 1. Construct indicator and measurement model of the variables.

\begin{tabular}{|c|c|c|c|c|c|}
\hline Constructs & Item & Theoretical Range & Loading & $\mathbf{C R} *$ & $\operatorname{AVE} * *$ \\
\hline \multirow{2}{*}{$\begin{array}{l}\text { Environmental strategic } \\
\text { planning }\end{array}$} & ESP2 & $1-7$ & 0.950 & \multirow[b]{2}{*}{0.841} & \multirow[b]{2}{*}{0.729} \\
\hline & ESP3 & $1-7$ & 0.745 & & \\
\hline \multirow{3}{*}{ Personnel controls } & PC2 & $1-7$ & 0.769 & \multirow[t]{3}{*}{0.837} & \multirow[t]{3}{*}{0.631} \\
\hline & PC3 & $1-7$ & 0.851 & & \\
\hline & PC4 & $1-7$ & 0.761 & & \\
\hline \multirow{5}{*}{ Environmental training } & ENVT1 & $1-7$ & 0.699 & \multirow[t]{5}{*}{0.912} & \multirow[t]{5}{*}{0.677} \\
\hline & ENVT2 & $1-7$ & 0.810 & & \\
\hline & ENVT3 & $1-7$ & 0.894 & & \\
\hline & ENVT4 & $1-7$ & 0.875 & & \\
\hline & ENVT5 & $1-7$ & 0.821 & & \\
\hline \multirow{4}{*}{$\begin{array}{c}\text { Radical environmental } \\
\text { innovation }\end{array}$} & RENVIN1 & $1-7$ & 0.765 & \multirow[t]{4}{*}{0.847} & \multirow[t]{4}{*}{0.582} \\
\hline & RENVIN2 & $1-7$ & 0.751 & & \\
\hline & RENVIN3 & $1-7$ & 0.698 & & \\
\hline & RENVIN4 & $1-7$ & 0.830 & & \\
\hline \multirow{3}{*}{ Economic performance } & $\mathrm{ROA}$ & & 0.936 & \multirow[t]{3}{*}{0.900} & \multirow[t]{3}{*}{0.751} \\
\hline & ROE & & 0.745 & & \\
\hline & ROI & & 0.907 & & \\
\hline
\end{tabular}

${ }^{*} \mathrm{CR}=$ composite reliability ${ }^{* *} \mathrm{AVE}=$ average variance extracted.

Table 2. Construct correlations and square root of the average variance extracted and the heterotraitmonotrait ratio.

\begin{tabular}{|c|c|c|c|c|c|c|c|c|c|}
\hline & 1 & 2 & 3 & 4 & 5 & 6 & 7 & 8 & 9 \\
\hline 1. Age & - & 0.045 & 0.148 & 0.332 & 0.081 & 0.105 & 0.027 & 0.071 & 0.446 \\
\hline 2. Economic performance & 0.020 & 0.867 & 0.097 & 0.106 & 0.080 & 0.150 & 0.071 & 0.083 & 0.055 \\
\hline 3. Environmental training & -0.139 & 0.083 & 0.823 & 0.080 & 0.283 & 0.810 & 0.094 & 0.190 & 0.130 \\
\hline 4. Gender & -0.332 & 0.098 & 0.066 & - & 0.046 & 0.082 & 0.046 & 0.141 & 0.101 \\
\hline 5. Personnel controls & 0.055 & -0.008 & 0.224 & 0.032 & 0.795 & 0.291 & 0.147 & 0.067 & 0.116 \\
\hline 6. Radical environmental innovation & -0.041 & 0.121 & 0.685 & -0.067 & 0.212 & 0.763 & 0.068 & 0.339 & 0.076 \\
\hline 7. Size & -0.027 & 0.064 & 0.026 & -0.046 & -0.125 & 0.058 & - & 0.173 & 0.014 \\
\hline 8. Environmental strategic planning & -0.067 & -0.068 & 0.050 & -0.131 & -0.028 & 0.274 & 0.129 & 0.854 & 0.222 \\
\hline 9. Tenure & 0.446 & -0.007 & 0.119 & -0.101 & 0.100 & -0.004 & -0.014 & -0.154 & - \\
\hline
\end{tabular}

The diagonal of the correlation matrix reports the square root of the AVE. The other side reports the heterotraitmonotrait ratios.

As seen in Table 2, the Fornell and Larcker criteria were met, showing that the constructs are distinct from one another. In the same way, the HTMT ratio was below 0.85 , thus complying with discriminant validity. In addition, the possible biases that the sample could be subjected to were tested. The first was the nonresponse bias, in which the first 10 respondents and last 10 respondents were compared [46]. The t-tests demonstrated no significant mean differences, with the exception of the environmental training variable. Similar results have been observed in related research $[47,48]$. The second test was for common method bias, in which the first factor of the explained total variance (0.35) was less than 0.5 [9]. Thus, the model is free from these biases.

\subsection{Structural Model}

This step allows us to test the hypotheses in our model using a path diagram. We use nonparametric bootstrapping techniques that consider 5000 subsamples with corrected and accelerated bias. Thus, the results in Table 3 show the hypothesized relationships and other non-hypothesized associations (control variables). 
Table 3. PLS structural model results.

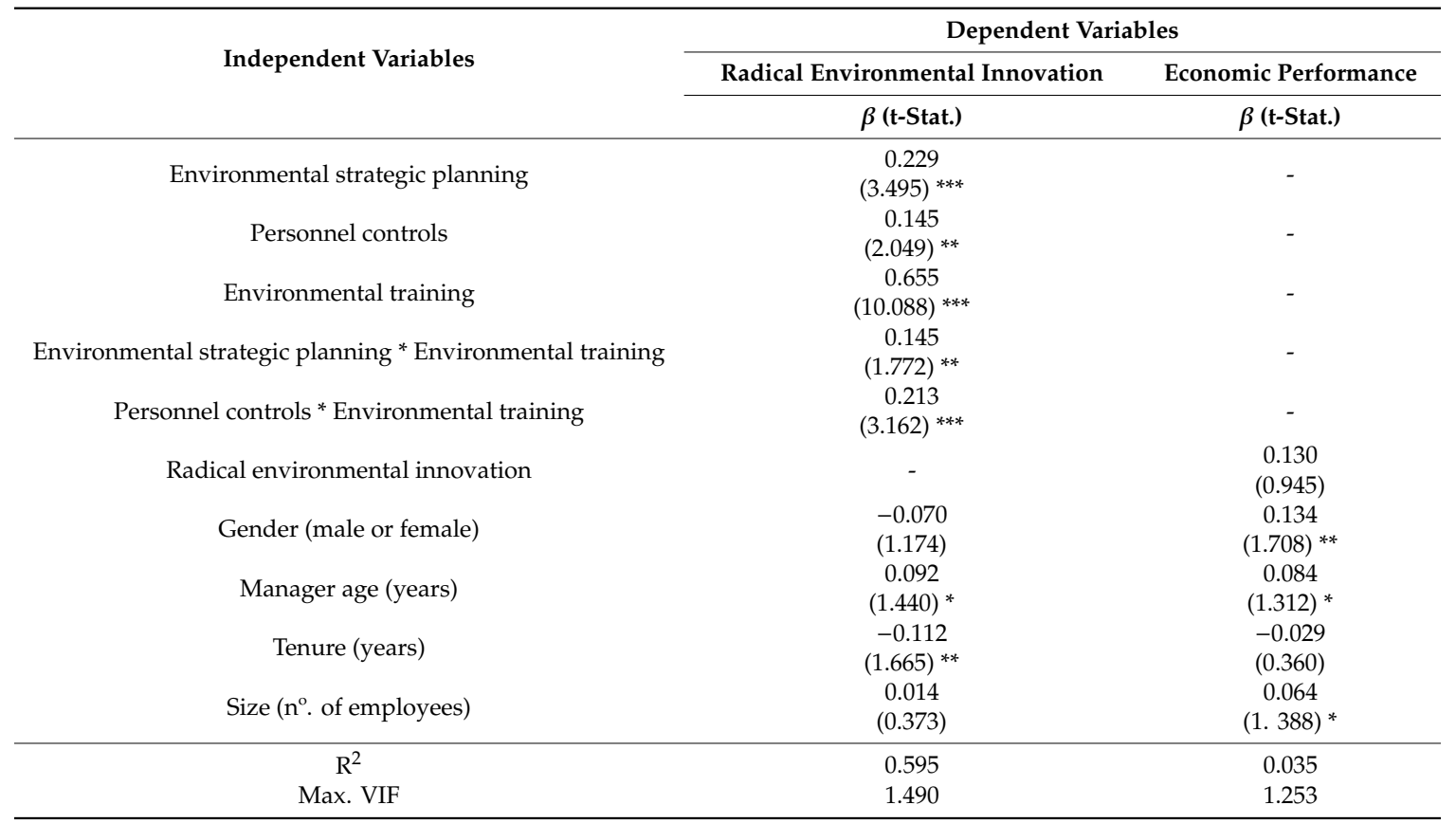

Standardized coefficients are presented. ${ }^{* * *}$ denote $1 \%$ significance level; ${ }^{* *}$ and ${ }^{*}$ denote $5 \%$ and $10 \%$ significance levels (one-tailed when the coefficient sign is predicted, two-tailed otherwise), respectively. $(-)=$ untested paths are represented by blank cells.

The first hypothesis predicts that environmental strategic planning positively affects REI. The result shows a positive and significant path coefficient $(\beta=0.229 ; p<0.01)$, providing support for H1. The second hypothesis predicts that personnel controls positively affect REI. The path coefficient provided evidence to support this hypothesis $(\beta=0.145 ; p<0.05)$.

We also tested the moderation effect of environmental training on the relationship between environmental strategic planning and REI. The results show a positive and significant path coefficient $(\beta=0.145 ; p<0.05)$, providing support for $\mathrm{H} 3 \mathrm{a}$. For $\mathrm{H} 3 \mathrm{~b}$, we tested the moderation effect of environmental training on the relationship between personnel controls and REI. The result demonstrates a positive and significant path coefficient $(\beta=0.213 ; p<0.01)$, supporting H3b. The interaction analysis is best illustrated in Figure 2.

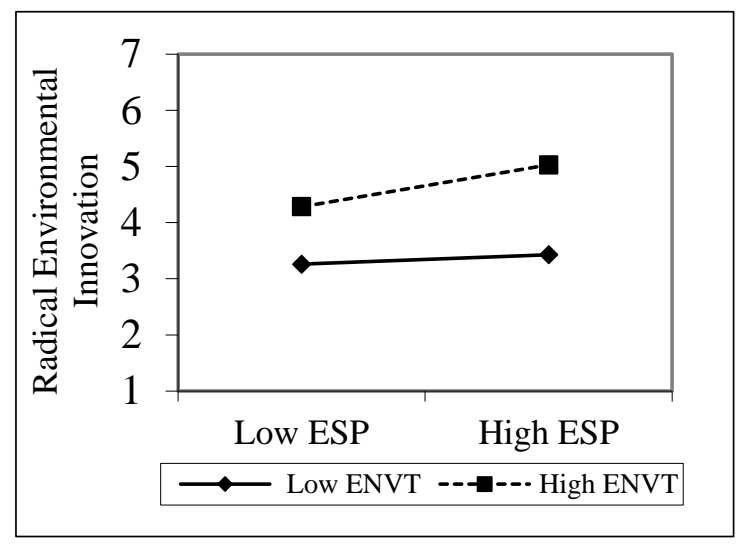

(ESP)

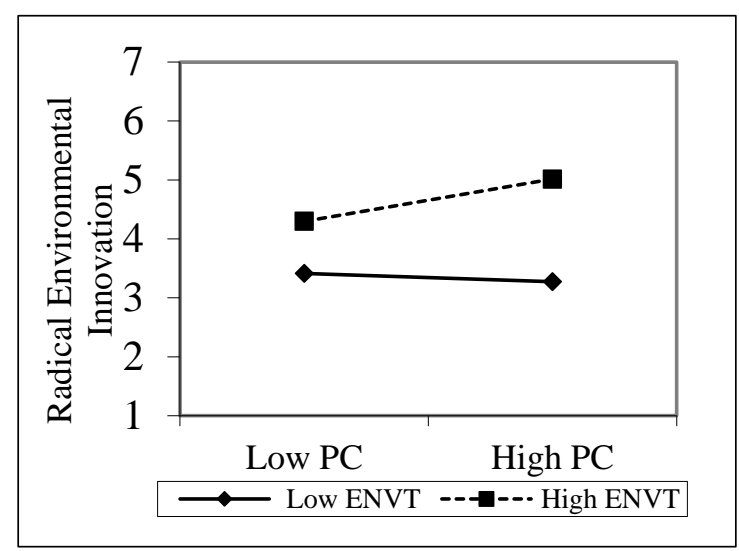

(PC)

Figure 2. Effect of the interaction between environmental strategic planning (ESP) and environmental training (ENVT), and the interaction effect of personnel controls (PC) and environmental training. 
It is possible to see that in high environmental training scenarios, the effect of environmental strategic planning on REI increases. Similarly, the more training increases, the stronger the influence of personnel controls on REI is.

For H4, we suggested that REI negatively affected economic performance. The results do not support the expectation that a high level of REI negatively influences economic performance $(\beta=0.130$; $p>0.10)$. Interestingly, the path coefficient was positive but not significant, suggesting that short-term REI does not result in significant economic performance. On the one hand, the control variables gender and size positively affected economic performance, and manager age also positively affected economic performance and REI. On the other hand, the manager's experience seems to be negatively associated with REI.

\subsection{Fuzzy-Set Qualitative Comparative Analysis}

As an additional analysis, we tested how the antecedents of REI behave via an asymmetric approach, as suggested by [42]. For this analysis, we adopted the FsQCA technique to identify the solutions that provide high REI. We consider a consistency threshold of 0.80 and observe sufficient combinations, as shown in Table 4.

Table 4. Combinations leading to high radical environmental innovation (REI).

\begin{tabular}{ccccccc}
\hline Solutions & $\begin{array}{c}\text { Personnel } \\
\text { Controls }\end{array}$ & $\begin{array}{c}\text { Environmental } \\
\text { Strategic } \\
\text { Planning }\end{array}$ & $\begin{array}{c}\text { Environmental } \\
\text { Training }\end{array}$ & $\begin{array}{c}\text { Unique } \\
\text { Coverage }\end{array}$ & $\begin{array}{c}\text { Raw } \\
\text { Coverage }\end{array}$ & Consistency \\
\hline 1 & $\bullet$ & $\bullet$ & $\bullet$ & 0.13 & 0.55 & 0.90 \\
2 & $\bullet$ & $\bullet$ & 0.11 & 0.53 & 0.92 \\
\hline Solution coverage & & \multicolumn{5}{c}{0.89} \\
\hline Solution consistency & $\bullet:$ Item taken into consideration.
\end{tabular}

The results indicate two possible intermediate solutions. The first solution suggests that the combination of personnel controls and environmental training predicts high REI. This solution is shared by $55 \%$ of respondents and has a consistency above the 0.80 threshold [43]. The second solution suggests the combination of environmental strategic planning and environmental training in the forecasting of high REI. This solution is shared by $53 \%$ of respondents and has a consistency of 0.92 . In general, the solution consistency was above 0.80 , which suggests the consistency of the identified combinations.

\section{Discussion}

The empirical evidence from this research reveals that REI is carried out using systematic innovation with continuous work practices and advanced technologies to launch new products and services that generate environmental benefits [2,3]. This corroborates the findings of [49] in verifying that in developing REI, companies are influenced by determining factors such as the government, markets and the integration of resources. This is because they use the services of companies specialized in environmental innovation and establish partnerships with their stakeholders (suppliers, customers or competitors).

The results also reveal that strategic environmental planning by companies is strongly related to REI [8]. Especially when environmental issues are explicitly considered in the company's strategic planning process, the top management team makes proactive and forward looking decisions. It is also possible that companies that use personnel control mechanisms in the selection, hiring and development of employees that end up supporting REI. These results show that similarly to innovation [20], personnel controls can be important in REI.

Environmental training positively influenced the relationship between strategic planning and personnel controls in REI. Previous studies have shown that training is important, as REI requires 
a high capacity to achieve the pre-established environmental goals [9]. Specifically, the surveyed companies revealed that the training is carried out continuously and systematically for employees, periodically for employees, continuously with suppliers, and continued with the local community. This empirical evidence is consistent with previous findings in revealing the importance of personnel controls and environmental training in the alignment of individual and institutional objectives $[5,9]$.

The findings emphasize that periodically conducting awareness-raising activities for environmental issues is crucial for companies that excel in environmental issues when they are creating new radically innovative products and services. Thus, under a scenario of a high degree of environmental training, both environmental strategic planning and personnel controls have a strong influence on REI. Therefore, it is important that organizations consider these variables in a combined manner.

From the results of the complementary FsQCA analysis, two solutions were found to be equally sufficient in predicting high REI. The findings of the combination of environmental strategic planning and environmental training notes that the great concern of organizations in preserving the environment, demonstrated through mission statements and business principles [4,8], increases REI. This is mainly because, through environmental training, stakeholders are constantly aware of adhering to ecologically sustainable actions. Similarly, the combination of personnel controls and REI reveals that organizations, in addition to excelling in the careful selection of employees, offer constant training $[18,19]$ to motivate managers to adhere to the organization's values, share the same interests that are inherent in ecological issues, and consequently reach high levels of REI. Hence, the integration of environmental strategic planning, personnel controls and environmental training plays a pivotal role within organizations that seek to innovate their products and services without neglecting environmental issues.

Organizations that invest in REI can have their economic performance reduced. The resources implemented to improve processes imply high risks and uncertainties, which in the short term, do not necessarily reflect an improvement in organizational performance. However, greater cooperation between actors in the value chain can mitigate these adverse effects in ways that together can develop sustainable technologies that allow for the adherence to innovation and the minimization of costs.

The concern with environmental issues implies process improvements that demand high investments, which in the long term can offer several benefits. For example, they can lead to competitive advantage since demand for ecologically sustainable products is increasing [50-52]. Hence, organizations concerned with sustainability can take advantage of the environmental innovation process. This is because these investments aimed at improving products, services, training and development can put the organization in a leadership position in the long term.

\section{Conclusions}

The purpose of this study is to analyze the effect of environmental training on the relationship between environmental strategic planning and personnel controls in radical environmental innovation for large companies. Data from 150 companies in the Brazil Stock Exchange (B3) were analyzed using structural equation modeling and FsQCA.

The results show that environmental strategic planning and personnel controls affect REI. Thus, inserting environmental issues into strategic planning helps achieve REI. Similarly, the results show that the process of selecting and contracting personnel directed at REI is fundamental for achieving environmental objectives. Environmental training impacts the relationship between environmental strategic planning and personnel controls in REI. Environmental training increases the impact of environmental strategic planning and personnel controls in REI, promoting individual and institutional alignment regarding sustainability.

This study has several theoretical and practical implications for companies. First, it is understood that there is are interactions among strategic planning, personnel controls and training in REI. It reveals the concern of preserving the environment that is formally presented in the company's strategy, increasing REI mainly through environmental training, as employees are constantly aware of ecologically sustainable actions. Similarly, the combination of personnel controls and REI reveals that organizations 
excel in the careful selection of employees, constant training and alignment of interests for ecological issues. Therefore, the interactions among environmental strategic planning, personnel controls and environmental training plays an important role for organizations in reaching REI in their products and services. It is also worth highlighting the relevance of environmental training since it aligns individual and organizational objectives and helps in achieving goals. Therefore, managers need to make greater efforts in terms of resources and knowledge through training to achieve REI, and these results apply in the long term.

Despite the robust results, this study is not without possible limitations. The results of the analysis represent the managers' perceptions regarding environmental strategic planning, personnel controls, environmental training and REI and thus may contain some response bias. The financial data of the companies used in the study were from a pandemic period (COVID-19); therefore, the results must consider the possible effects caused by this event. Despite these limitations, the results of the study are an important addition to the knowledge about the management of REI. For future research, we recommend studies that consider other controls, such as results, action and culture, in addition to budgeting, the planning process and mission statement, which may affect and provide broader empirical evidence about REI. Additionally, future studies should consider artificial neural networks to complement SEM analysis and verify which input is the most important in the model to predict the outcome.

Author Contributions: All authors were involved in the conception, design, and writing of the manuscript. Conceptualization, R.J.L., F.S.d.R. and J.J.M.; formal analysis, J.J.M.; investigation, D.A.B.; methodology, R.J.L. and F.S.d.R.; project administration, D.A.B.; resources, R.J.L.; validation, J.J.M.; writing-original draft, D.A.B.; and writing-review and editing, F.S.d.R. All authors have read and agreed to the published version of the manuscript.

Funding: This publication has been developed with support from Conselho Nacional de Desenvolvimento Científico e Tecnológico-CNPq (Processo No. 305812/2018-1) and Coordenação de Aperfeiçoamento de Pessoal de Nível Superior-CAPES (Processo No. 88887.468904/2019-00).

Acknowledgments: We would like to acknowledge the support of Conselho Nacional de Desenvolvimento Científico e Tecnológico-CNPq and Coordenação de Aperfeiçoamento de Pessoal de Nível Superior-CAPES.

Conflicts of Interest: The authors declare no conflict of interest.

\section{References}

1. Liao, Z.; Zhang, M. The influence of responsible leadership on environmental innovation and environmental performance: The moderating role of managerial discretion. Corp. Soc. Responsib. Environ. Manag. 2020, 1-12. [CrossRef]

2. Jiménez, O. Innovation-Oriented Environmental Regulations: Direct Versus Indirect Regulations; An Empirical Analysis of Small and Medium-Sized Enterprises in Chile. Environ. Plan. A 2005, 37, 723-750. [CrossRef]

3. Dragomir, V.D. Theoratical, Practical and Ethical Aspects. In Corporate Environmental Strategy. Springer Briefs in Applied Sciences and Technology; Springer: Cham, Switzerland, 2020. [CrossRef]

4. Latan, H.; Jabbour, C.J.C.; Sousa Jabbour, A.B.L.; Renwick, D.W.S.; Wamba, S.F.; Shahbaz, M. 'Too-much-of-a -good-thing'? The role of advanced eco-learning and contingency factors on the relationship between corporate environmental and financial performance. J. Environ. Manag. 2018, 220, 163-172. [CrossRef] [PubMed]

5. Goebel, S.; Weißenberger, B.E. The Relationship between Informal Controls, Ethical Work Climates, and Organizational Performance. J. Bus. Ethics. 2017, 141, 505-528. [CrossRef]

6. Mendes, A.; Lunkes, R.J.; Flach, L.; Kruger, S.D. The influence of remuneration on the behavior of hospital employees in Brazil. Contaduría Y Adm. 2017, 6, 207-221. [CrossRef]

7. Theyel, G. Management practices for environmental innovation and performance. Int. J. Oper. Prod. Manag. 2000, 20, 249-266. [CrossRef]

8. Wisner, P.S.; Epstein, M.J.; Bagozzi, R.P. Organizational Antecedents and Consequences of Environmental Performance. In Environmental Accounting (Advances in Environmental Accounting \& Management, Vol. 3); Freedman, M., Jaggi, B., Eds.; Emerald Group Publishing Limited: Bingley, UK, 2006; pp. 143-167. [CrossRef]

9. Gomez-Conde, J.; Lunkes, R.J.; Rosa, F.S. Environmental innovation practices and operational performance: The joint effects of management accounting and control systems and environmental training. Account. Audit Account. J. 2019, 32, 1325-1357. [CrossRef] 
10. Berchicci, L.; Bodewes, W. Bridging environmental issues with new product development. Bus. Strat. Environ. 2005, 14, 272-285. [CrossRef]

11. Dai, J.; Cantor, D.E.; Montabon, F.L. How Environmental Management Competitive Pressure Affects a Focal Firm's Environmental Innovation Activities: A Green Supply Chain Perspective. J. Bus. Logist. 2015, 36, 242-259. [CrossRef]

12. Mothe, C.; Nguyen-Thi, U. Openness and Environmental Innovation: Does Time-Horizon Matter? Luxembourg Institute of Socio-Economic Research (LISER) Working Paper Series 2016-13. 2016. Available online: https://ssrn.com/abstract=2849364; http://dx.doi.org/10.2139/ssrn.2849364 (accessed on 9 March 2020).

13. Subramaniam, M.; Youndt, M.A. The influence of intellectual capital on the types of innovative capabilities. Acad. Manag. J. 2005, 48, 450-463. [CrossRef]

14. Bisbe, J.; Malagueño, R. The choice of interactive control systems under different innovation management modes. Eur. Account. Rev. 2009, 18, 371-405. [CrossRef]

15. Bedford, D.S.; Bisbe, J.; Sweeney, B. Performance measurement systems as generators of cognitive conflict in ambidextrous firms. Account. Organ. Soc. 2019, 72, 21-37. [CrossRef]

16. Hagen, O. Driving environmental innovation with corporate storytelling: Is radical innovation possible without incoherence? Int. J. Innov. Sustain. Dev. 2008, 3, 217-233. [CrossRef]

17. Curtis, E.; Sweeney, B. Managing different types of innovation: Mutually reinforcing management control systems and the generation of dynamic tension. Account. Bus. Res. 2017, 47, 313-343. [CrossRef]

18. Merchant, K.A.; Van der Stede, W.A. Management Control Systems; Pearson Education Limited: Edinburgh Gate, UK, 2012.

19. Kleine, C.; Weißenberger, B.E. Leadership impact on organizational commitment: The mediating role of management control systems choice. J. Manag. Control. 2014, 24, 241-266. [CrossRef]

20. Pesämaa, O. Personnel-and action control in gazelle companies in Sweden. J. Manag. Control. 2017, 28, 107-132. [CrossRef]

21. Antonioli, D.; Mancinelli, S.; Mazzanti, M. Is environmental innovation embedded within high-performance organisational changes? The role of human resource management and complementarity in green business strategies. Res. Policy 2013, 42, 975-988. [CrossRef]

22. Chang, C.H. The influence of corporate environmental ethics on competitive advantage: The mediation role of green innovation. J. Bus. Ethics 2011, 104, 361-370. [CrossRef]

23. Forsman, H.; Temel, S.; Uotila, M. Towards sustainable competitiveness: Comparison of the successful and unsuccessful eco-innovators. Int. J. Innov. Manag. 2013, 17, 45-70. [CrossRef]

24. Lopez-Valeiras, E.; Gomez-Conde, J.; Naranjo-Gil, D. Sustainable Innovation, Management Accounting and Control Systems, and International Performance. Sustainability 2015, 7, 3479-3492. [CrossRef]

25. Weng, H.H.R.; Chen, J.S.; Chen, P.C. Effects of green innovation on environmental and corporate performance: A stakeholder perspective. Sustainability 2015, 7, 4997-5026. [CrossRef]

26. Shih, T.Y. Determinants of Enterprises Radical Innovation and Performance: Insights into Strategic Orientation of Cultural and Creative Enterprises. Sustainability 2018, 10, 1871. [CrossRef]

27. Sarkis, J.; Cordeiro, J.J. An empirical evaluation of environmental efficiencies and firm performance: Pollution prevention versus end-of-pipe practice. Eur. J. Oper. Res. 2001, 135, 102-113. [CrossRef]

28. Rosenbusch, N.; Brinckmann, J.; Bausch, A. Is innovation always beneficial? A meta-analysis of the relationship between innovation and performance in SMEs. J. Bus. Ventur. 2011, 26, 441-457. [CrossRef]

29. Horváthová, E. The impact of environmental performance on firm performance: Short-term costs and long-term benefits? Ecol. Econ. 2012, 84, 91-97. [CrossRef]

30. Hall, J.; Clark, W. Special Issue: Environmental Innovation. J. Clean. Prod. 2003, 11, 343-346. [CrossRef]

31. Kennedy, S.; Whiteman, G.; Van den Ende, J. Radical Innovation for Sustainability: The Power of Strategy and Open Innovation. Long Range Plan. 2017, 50, 712-725. [CrossRef]

32. Naranjo-Gil, D. The Role of Management Control Systems and Top Teams in Implementing Environmental Sustainability Policies. Sustainability 2016, 8, 359. [CrossRef]

33. Naranjo-Tuesta, Y.; Crespo-Soler, C.; Ripoll-Feliu, V. The Influence of Carbon Management on the Financial Performance of European Companies. Sustainability 2020, 12, 4951. [CrossRef]

34. Widener, S.K. An empirical investigation of the relation between the use of strategic human capital and the design of the management control system. Account. Organ. Soc. 2004, 29, 377-399. [CrossRef] 
35. Bisbe, J.; Otley, D. The effects of the interactive use of management control systems on production innovation. Account. Organ. Soc. 2004, 29, 709-737. [CrossRef]

36. Davila, T. An Exploratory Study on the Emergence of Management Control Systems: Formalizing Human Resources in Small Growing Firms. Account. Organ. Soc. 2005, 30, 223-248. [CrossRef]

37. Fujii, H.; Iwata, K.; Kaneko, S.; Managi, S. Corporate environmental and economic performance of Japanese manufacturing firms: Empirical study for sustainable development. Bus. Strat. Environ. 2013, 22, 187-201. [CrossRef]

38. Dillman, D.A.; Smyth, J.D.; Cristian, L.M. Internet, Phone, Mail, and Mixed-Mode Surveys: The Tailored Design Method, 4th ed.; Wiley: New York, NY, USA, 2014.

39. Instituto Brasileiro de Geografia e Estatística-IBGE. Pesquisa de Inovação (PINTEC). 2017. Available online: https://sidra.ibge.gov.br/pesquisa/pintec/tabelas (accessed on 5 May 2020).

40. Hair, J.F., Jr.; Hult, G.T.M.; Ringle, C.; Sarstedt, M. A Primer on Partial Least Squares Structural Equation Modeling (PLS-SEM); Sage Publications: Los Angeles, CA, USA, 2016.

41. Lunkes, R.J.; Rosa, F.S.; Lattanzi, P. The Effect of the Perceived Utility of a Management Control System with a Broad Scope on the Use of Food Waste Information and on Financial and Non-Financial Performances in Restaurants. Sustainability 2020, 12, 6242. [CrossRef]

42. Kaya, B.; Abubakar, A.M.; Behravesh, E.; Yildiz, H.; Mert, I.S. Antecedents of innovative performance: Findings from PLS-SEM and fuzzy sets (fsQCA). J. Bus. Res. 2020, 114, 278-289. [CrossRef]

43. Ragin, C.C. Qualitative comparative analysis using fuzzy sets (fsQCA). In Configurational Comparative Methods: Qualitative Comparative Analysis (QCA) and Related Techniques; Sage Publications: Thousand Oaks, CA, USA, 2009; Volume 51, pp. 87-121. [CrossRef]

44. Ferreira, P.J.S.; Dionísio, A.T.M. What are the conditions for good innovation results? A fuzzy-set approach for European Union. J. Bus. Res. 2016, 69, 5396-5400. [CrossRef]

45. Crespo, N.F.; Rodrigues, R.; Samagaio, A.; Silva, G.M. The adoption of management control systems by start-ups: Internal factors and context as determinants. J. Bus. Res. 2019, 101, 875-884. [CrossRef]

46. Af Wåhlberg, A.E.; Poom, L. An empirical test of nonresponse bias in internet surveys. Basic Appl. Soc. Psychol. 2015, 37, 336-347. [CrossRef]

47. De Harlez, Y.; Malagueno, R. Examining the joint effects of strategic priorities, use of management control systems, and personal background on hospital performance. Manag. Account. Res. 2016, 30, 2-17. [CrossRef]

48. Müller-Stewens, B.; Widener, S.K.; Möller, K.; Steinmann, J.C. The role of diagnostic and interactive control uses in innovation. Account. Organ. Soc. 2020, 80, 101078. [CrossRef]

49. Jiao, J.; Wang, C.; Yang, R. Exploring the driving orientations and driving mechanisms of environmental innovation: The case study of the China Gezhouba. J. Clean. Prod. 2020, 260, 121016. [CrossRef]

50. Fogarty, F.; Villamagna, A.; Whitley, A.; Pippins, K. The Capacity to Endure: Following Nature's Lead. Sustainability 2013, 5, 2480-2494. [CrossRef]

51. Jorge, E.; Lopez-Valeiras, E.; Gonzalez-Sanchez, M.B. The role of attitudes and tolerance of ambiguity in explaining consumers' willingness to pay for organic wine. J. Clean. Prod. 2020, 257, 120601. [CrossRef]

52. Kim, B.; Lee, S. The impact of material and immaterial sustainability on firm performance: The moderating role of franchising strategy. Tour. Manag. 2020, 77. [CrossRef]

Publisher's Note: MDPI stays neutral with regard to jurisdictional claims in published maps and institutional affiliations.

(C) 2020 by the authors. Licensee MDPI, Basel, Switzerland. This article is an open access article distributed under the terms and conditions of the Creative Commons Attribution (CC BY) license (http://creativecommons.org/licenses/by/4.0/). 